\title{
UNA LECTURA PARALELA DE HISTORIA Y ARQUITECTURA VERNÁCULA AGRÍCOLA ENTRE LOS MONTES DE TOLEDO Y EL RÍO TAJO
}

\author{
ADELAIDA DEL PUERTO, \\ Escuela Técnica Superior de Arquitectura \\ Universidad Politécnica de Madrid
}

\section{Resumen}

La arquitectura vernácula aislada, ligada a la agricultura, es un catalizador de procesos históricos y de la evolución de las relaciones entre hombre y territorio. El objetivo de esta investigación ha sido analizar la influencia del aislamiento y desprotección sobre estas arquitecturas, que viven bajo el influjo constante de la sucesión de pueblos y culturas sobre un área determinada. Obligadas a relacionarse de forma estrecha con el paisaje, disponen únicamente de recursos locales para su ejecución. Ambas premisas las convierten en un campo de estudio histórico y paisajístico de gran interés. El análisis de los casos estudiados en la franja de territorio entre los Montes de Toledo occidentales y el río Tajo, territorio fronterizo desde época prerromana y hasta avanzada la Edad Media, dejan patentes los procesos de evolución cultural desde tiempos prerromanos y hasta el Renacimiento.

Palabras clave:

arquitectura vernácula, arquitectura e historia, Tajo, Toledo, Montes de Toledo.

\section{HISTORY AND VERNACULAR ARCHITECTURE RELATED TO FARMING BETWEEN MONTES DE TOLEDO AND RIVER TAGUS: A PARALLEL STORY.}

\section{Abstract}

Vernacular isolated architecture, related to agriculture, is a catalyst of historical processes and of the evolution of the relationship between mankind and territory. The aim of this research has been to analyze the influence of isolation and vulnerability on these examples of architecture. Case studies have been extremely related to landscape and constantly down by peoples and cultures dominating the territory over time, with their subsequent mark on typologies and constructive solutions. Forced to interact with the surrounding landscape, local resources have been the only means for construction. In the case of the fringe of land between Toledo mountains and river Tagus, a border territory from pre-roman times until Renaissance, preliminar studies make clear the historical processes into the architectural types.

$$
\text { Keywords: }
$$

vernacular architecture, architecture and history, Tagus, Toledo, architecture and landscape. 


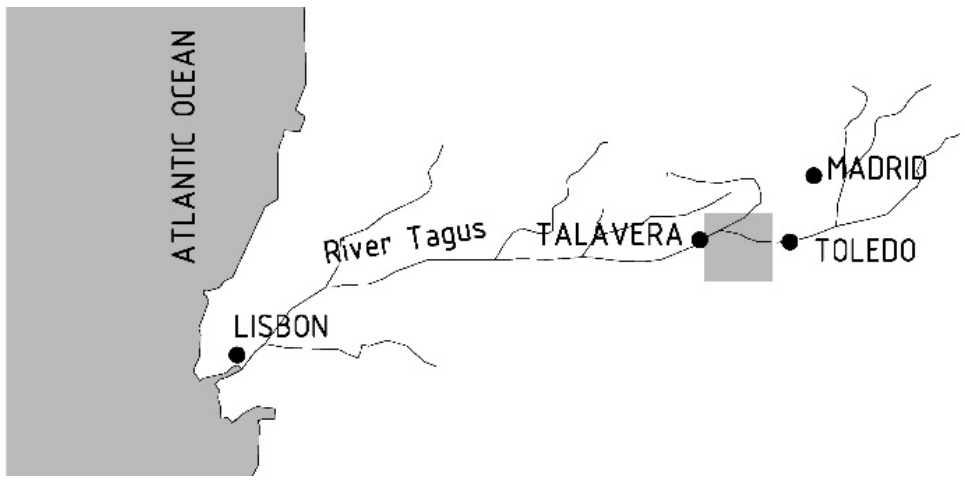

Fig.1. Área de estudio, esquema de localización en la península ibérica. Fuente: La autora

\section{Introducción}

Son escasos los estudios detallados sobre la arquitectura vernácula en la franja de territorio entre los Montes de Toledo occidentales y el río Tajo. En esa área la arquitectura aislada, que ha servido a la explotación agrícola y ganadera del territorio hasta mediados del siglo XX, varía enormemente en un descenso desde la cordillera hasta el río. Esas variaciones son producto de las variaciones en la composición del suelo, de las especies botánicas y de la orografía. Pero también del aprovechamiento o no de cada Altitud por parte de las diferentes culturas que han invadido ese territorio. Un territorio que ha sido fronterizo desde que los Carpetanos y los Vettones se repartían el curso medio del Tajo, durante la invasión romana en frontera con la Lusitania, hasta formar parte de la Marca Media del mundo musulmán y convertirse en primera zona de avance de la reconquista hacia la meseta sur en la Edad Media. Todo ello, unido a la escasa modificación parcelaria y de propiedad de las fincas en la vega del Tajo durante las desamortizaciones del siglo XIX, ha determinado soluciones tipológicas muy diferentes que han sido objeto de análisis comparativo en esta investigación.

\section{Objetivos del estudio}

Han sido objetivos generales de este estudio el establecer las variaciones de la arquitectura en relación con la Historia y determinar las influencias en la arquitectura vernácula aislada de las diferentes culturas que han definido la evolución del territorio entre los Montes de Toledo y el río Tajo. Hacer, a su vez, una lectura histórica a través de las edificaciones que han llegado hasta la actualidad, ha sido otro de los fines de esta investigación que pretende dejar constancia de un patrimonio etnográfico que se mueve entre la arquitectura y la arqueología, dado el avanzado estado de abandono de los casos de estudio.

\section{Metodología}

El trabajo se ha dividido en tres fases. Una primera fase de búsqueda de cartografía y fondos de Archivos en los que se han localizado las edificaciones aisladas más relevantes. Una segunda fase de trabajo de campo dentro y fuera de nuestra geografía, con toma de datos directa de las edificaciones como levantamientos croquis e imágenes fotográficas. Una tercera fase de análisis ha consistido en el estudio combinado de bibliografía acerca de los procesos históricos de la zona y de las soluciones constructivas tipo de los diferentes pobladores.

\section{Localización geográfica del área de estudio}




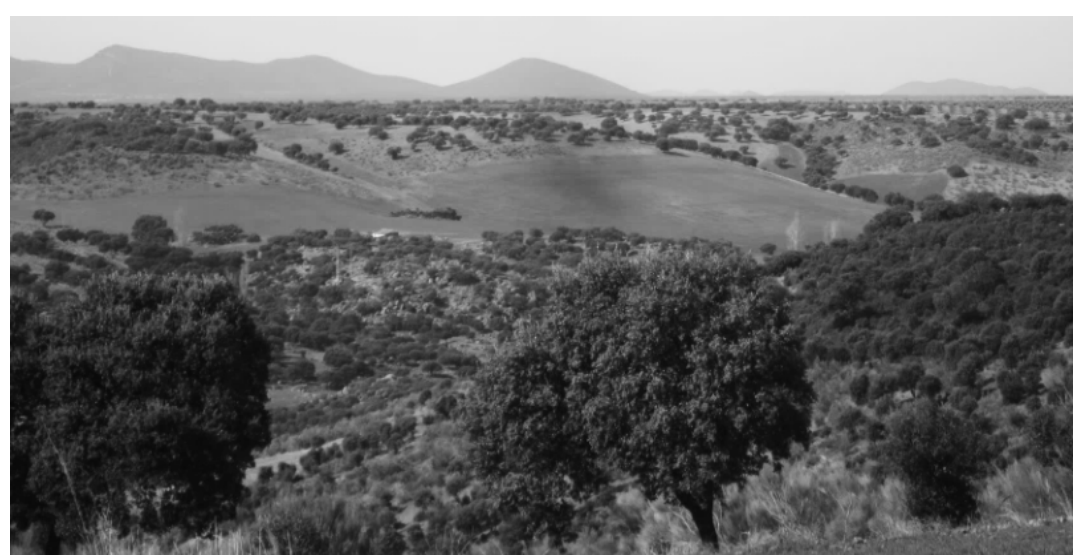

Fig. 2. Paisaje en las estribaciones de los Montes de Toledo. Fuente: la autora

El curso medio del río Tajo, a su paso por la provincia de Toledo, genera un macromeandro que coincide con las zonas de mayor altitud de la Cordillera de los Montes de Toledo. Esa franja de territorio es conocida desde la Edad Media como las montañas pertenecientes a la ciudad de Toledo. ${ }^{1}$

Se trata de una zona de mayores recursos naturales que las zonas circundantes debido a su mayor pluviometría, su orientación norte y la aparición de varios ríos cercanos entre sí. Ha sido zona de explotación minera ${ }^{2}$ desde la ocupación romana y de recursos forestales y cinegéticos durante toda la Edad Media y hasta el s. XX.

Las variaciones en las distancias entre el río Tajo y la cordillera genera grandes contrastes paisajísticos en pequeñas distancias. La topografía, casi llana en las inmediaciones del río Tajo se convierte en accidentada a pocos kilómetros superando los $1.000 \mathrm{~m}$. de altitud.

\section{Principales elementos y variaciones del paisaje natural entre los Montes de Toledo y el río Tajo}

Las variaciones en las distancias entre la cordillera y el río vienen determinadas por la topografía, mucho más suave en las inmediaciones del río, y accidentada con cotas que superan los 1.000 metros en la cordillera. También por la composición del suelo; granitos y arenas frecuentes en la franja más oriental, que dan paso a arcillas y pizarra a medida que nos acercamos al límite oeste. Las especies botánicas silvestres, a su vez, aumentan su porte con la aparición de encinares y robledales en las estribaciones. Disminuyen en cantidad y capacidad de obstaculizar la visión del horizonte en un acercamiento hacia el río, a cuyos lados se desarrolla una agricultura donde predominan los cultivos de herbáceos en contraste con el cultivo del olivo predominante en las estribaciones.

\section{Una visión histórica transversal y ejemplos de arquitectura desde la cordillera hasta el río}

La cordillera de los Montes de Toledo, que se mueve de Este a Oeste de la provincia a lo largo de su límite sur, alcanza su punto de máxima altitud en el pico del Rocigalgo, con 1447 $\mathrm{m}$. Ese es el origen de la sección transversal a los Montes que sirve de base para este estudio y que desciende hasta los $360 \mathrm{~m}$. en la Vega de Talavera de la Reina. La jurisdicción de Los Montes de Toledo se define hasta 1500 como aquel territorio "de 17 leguas de Este a Oeste

\footnotetext{
${ }^{1}$ Palomeque, 1954.

2 Minas ferruginas: método de explotación `ruina montium' según Olaguer Feliú, 1977.
} 

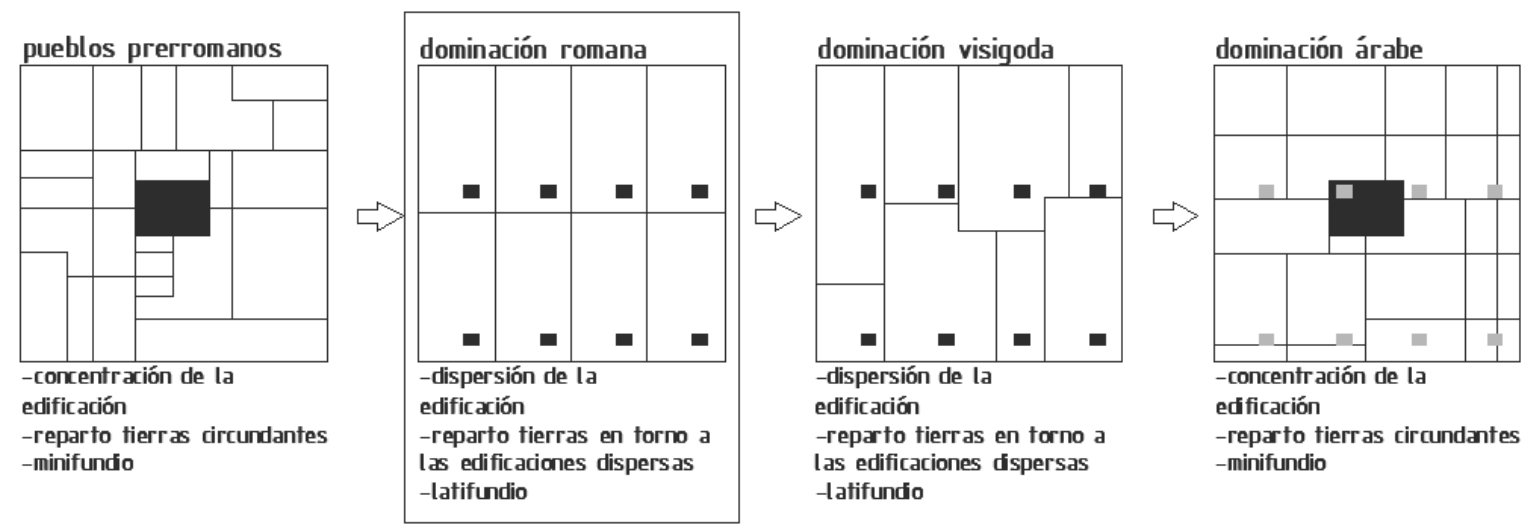

Fig. 3. Croquis evolución estructuras paralelas. Fuente: la autora

y de 11 leguas de Norte a Sur en la Margen Izquierda del Río Tajo". ${ }^{3}$ Una breve, pero concisa descripción del paisaje de vega estudiado, se da durante la campaña de Talavera de la Guerra de la independencia por parte de un militar británico:

The valley of the Tagus, into wich the army was about to plunge, is intersected by several rivers, with rugged Banks and deep channels; but their courses being very Little out of the parallel of the Tagus, the Alberche is in a manner enclosed. ${ }^{4}$

Su paisaje natural se ha visto transformado por la acción del hombre desde la antigüedad y con mayor intensidad desde el s. XVI. Su actual conformación es el resultado de diferentes procesos de reparto de la tierra cuyas diferencias se sintetizan en el siguiente gráfico comparativo:

Los pueblos prerromanos, con fronteras inestables y escasos medios de protección, concentraban la edificación en grandes castros ubicados en cerros de fácil defensa. Es el caso de los Carpetanos, habitantes de la zona de estudio a la llegada de los romanos. “(...) ciudades aldeas y castillos campestres, que parecen corresponder a los existentes en las poblaciones pastoriles actuales de los países esteparios, que se agrupan alrededor de una edificación mayor o menor que sirve de almacén y que están organizadas siguiendo un sistema patriarcal de jerarquías hereditarias (...). Muchas de las ciudades carpetanas se hallaban en riscos y escarpaduras con cuevas naturales o artificiales que servían a la gente de mansiones". ${ }^{5}$

Los Carpetanos, que habitaban los escarpes contiguos al río Tajo, basaban su economía en la ganadería y, al parecer, en una agricultura que comprendía ya el cultivo del olivo. "En 146 Viriato (Ib. 64) saquea la Carpetania a la que se define como un país rico, al parecer agrícola (con olivos incluidos) ya que Viriato exige el valor de las cosechas bajo amenaza de destruirlas". ${ }^{6}$

Pero en la zona estudiada, los asentamientos eran de pequeño tamaño y en frontera continua con Vettones a noroeste, Oretanos al sur y Vacceos a Norte. También se apunta en algunos textos y, a raíz de los hallazgos de objetos orientalizantes, al contacto de los pueblos fenicios con los pueblos indígenas de la zona a través del cauce del Tajo. Es muy escasa la información acerca de los modos de construcción prerromana en la zona. Lo más

\footnotetext{
${ }^{3}$ Palomeque, 1954.

${ }^{4}$ Napier, 1814: 365.

${ }^{5}$ Caro Baroja, 1946: 282-291.

${ }^{6}$ Urbina, 1998: 190.
} 
Fig. 4. Mapa de reparto de territorio entre los pueblos prerromanos. Fuente: la autora

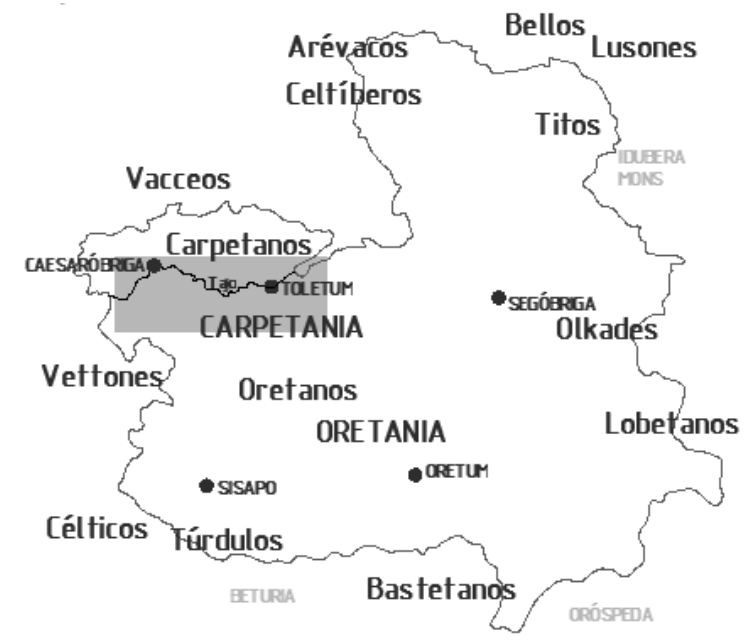

probable es que no difirieran en exceso de los hallados con más abundancia en la zona de penetración de planta rectangular de origen céltico en la segunda edad del hierro, que dejó las plantas circulares tan sólo en el noroeste peninsular. De esta forma predominaría la llamada cultura de La Tené, de la segunda edad del hierro, en la que los habitantes prerromanos disponen hasta al menos el s. II de casas rectangulares.

De forma simultánea, en otras latitudes de la cuenca mediterránea, irán evolucionando formas urbanas y soluciones constructivas que tardarán siglos en llegar a la zona. Se irán incorporando a las soluciones tipo con el paso del tiempo y las variaciones propias de topografía y materiales disponibles.

Los fenicios, asentados en la desembocadura del Tajo -actual Lisboa- y poco interesados en las conquistas de territorio tierra adentro, establecerían relaciones de exportación e importación desde el Atlántico hacia el interior por el cauce del río Tajo. Los intercambios podrían ser entonces entre objetos de artesanía fenicia de alta calidad y productos del lugar como aceite de oliva o metales. Es más difícil que se vieran importadas sus técnicas constructivas aunque se conocen los intercambios de información y cesión temporal de arquitectos por parte del Rey fenicio Hiram I de Tiro (s. X a. C.) a su cliente judío el Rey Salomón, ${ }^{7}$ cuyos principales bienes de pago eran principalmente los productos agrícolas.

"La idea de que el cauce del Tajo podría ser una de las vías de introducción del orientalizante hacia el interior, desde asentamientos fenicios en la costa fue una proposición de Frankestein (1997:201 ss.) a partir de la que Schüle definió como Cultura del Tajo, que el continuo descubrimiento en su estuario de factorías y de poblados con una importante cultura orientalizante convierte cada vez en más relevante( Arruda, $1993 ; 2000)(\ldots)$ crucial por lo que se refiere a sus efectos en las perspectivas sobre la protohistoria de la cuenca del Tajo. (...) y puntos estratégico como Santarem, pueden ya ser mejor entendidos como una etapa intermedia en los asentamientos fenicios que probablemente se extendieron hacia el interior (...). Desde el núcleo del Mar de Palha, el camino más corto para acceder al interior de la Meseta es el cauce del Tajo, simplemente remontando y superando las escasas alturas de la Beira Baixa, apenas a dos jornadas de la zona de Alcántara, y desde allí hasta el interior. Es obligado poner en valor la cualidad misma del Tajo como línea de comunicación ancestral entre el Ribatejo y la Alta Extremadura (Álvarez y Gil, 1998) tanto a los efectos de fácil navegación y como consecuencia de las implicaciones que tendría na elevada población fenicia en uno

\footnotetext{
7 Antiguo Testamento, II crónicas, 8 y 9 y Reyes, 5 y 9. Información ampliada sobre esta figura histórica: Javier Alonso, 2002 y Hamblin\&Rolph, 2007.
} 


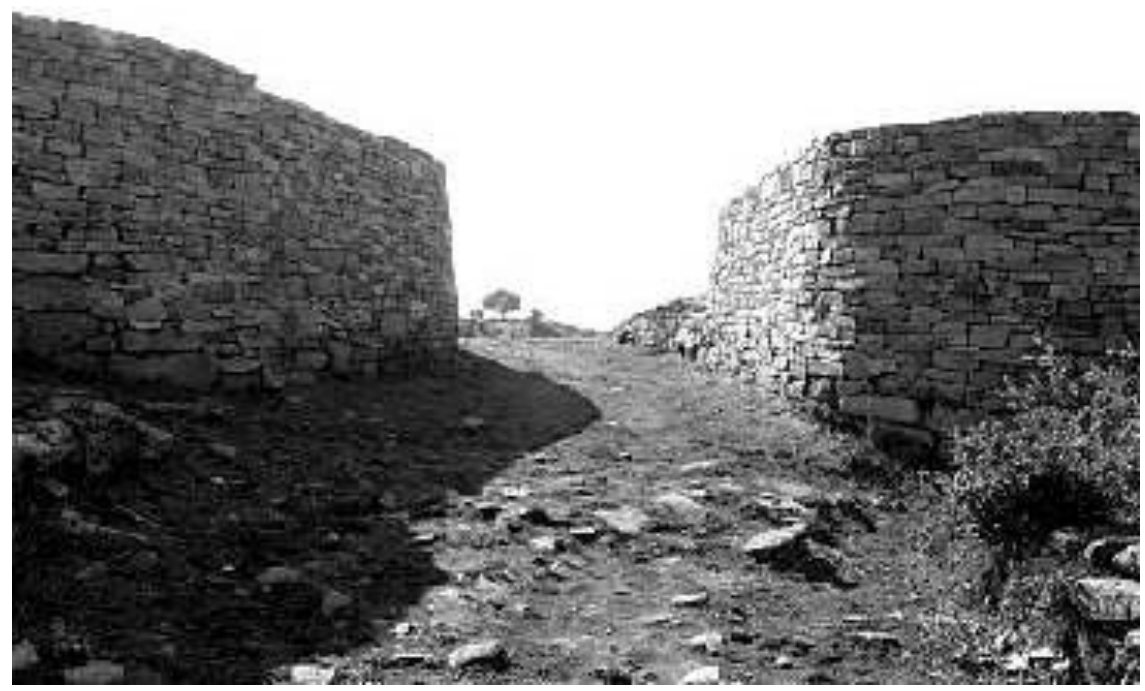

Fig.5. Imagen del castro celtíbero de las Cogotas. Fuente:http://www.espaciorural.co $\mathrm{m} /$ rutas/85/Castro_de_Las_Cogot as.html

de sus extremos". 8 "Uno de los pactos más conocidos fue el que realizó con el rey Salomón de Israel en relación con la construcción del Templo y el palacio del rey en la ciudad de Jerusalén. Hiram envió maderas sagradas - cedros y cipreses- y algunos de sus mejores arquitectos para erigir el gran templo; a cambio, el fenicio fue recompensado durante años con cantidades regulares de trigo y aceite". 9

Durante la dominación romana se darán profundos cambios en los sistemas de poblamiento generándose gran cantidad de asentamientos ex novo. Los efectos de la colonización romana fueron los de un desmembramiento completo del sistema de asentamientos y relaciones entre las diferentes poblaciones y del sistema territorial y político, creando otro orden nuevo dentro del cual estaba incluida una nueva percepción geográfica.

"En regiones conocidas y famosas se pueden saber los movimientos de población, las divisiones territoriales, los cambios de nombre y otras circunstancias análogas (...). Mas cuando se trata de regiones bárbaras y lejanas, pequeñas y subdivididas, los informes son ya poco seguros y escasos". ${ }^{10}$

Los romanos dotados de medios de defensa y necesitados de grandes producciones agrícolas tanto para servir a sus urbes como a sus ejércitos, basarán su dominación del territorio en la explotación de las vegas y las zonas de alta producción agrícola. Dejarán el dominio de territorios más inaccesibles bajo la supervisión de pequeños núcleos o fortificaciones. Tal es el caso del yacimiento de Hontanar, a unos $850 \mathrm{~m}$. de altitud.

"En las relaciones de Felipe II de 1596 contestadas por Hontanar, se menciona la necrópolis rupestre diciendo que ay muchas sepulturas hechas en piedra bivas de siete pies de largo y algunas de ocho." También lo hace el Conde de Mora en su Historia de Toledo al referirse a "y... sepulcros e inscripciones con letras latinas que por la antigüedad están gastadas las letras, que no se han podido leer". ${ }^{11}$

Una de las evidencias del importante proceso de romanización de la Cuenca Media del Tajo, en la que se encuentran las vegas de la zona estudiada, es el reparto de yacimientos

\footnotetext{
${ }^{8}$ II Congreso Arqueología Provincia de Toledo Vol. I, 2001: 308-309.

${ }^{9}$ Prados, 2007: 92.

${ }^{10}$ Jiménez de Gregorio, 1966: 308-309.

${ }^{11}$ Leblic, 2013: 23.
} 


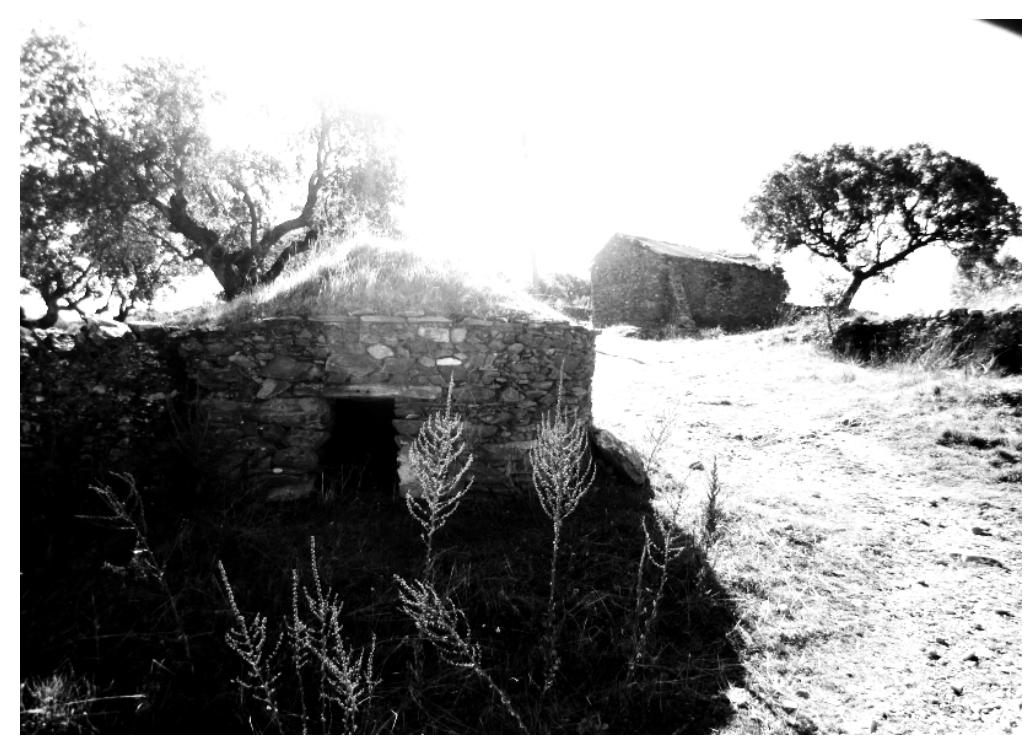

Fig. 6. Imagen actual de edificación principal y establo destinados a uso agrícola/ganadero en Los Alares, Toledo $850 \mathrm{~m}$. altitud. Fuente: la autora.

romanos. Tanto las grandes infraestructuras como las Villas, mausoleos y otros hallazgos se encuentran en su mayor parte cercanos a la cuenca además de en el tramo entre Toledo y Talavera de la Reina en su mayoría.

Como os servidores civis, os soldados recebem um campo para satisfacer as suas necesidades. O escriba da tropa colocaa sob as ordens de Awel Marduk inform Hamurabi que os homens nao receberam oscampos aos quais têm direito. O rei ordena ao administrador que lhes dê satisfacao. (...) Ignora-se como êles eran recrutados. Talve fôssem habitantes de certas regioes, deslocados da sua profissao depois da conquista. No imperio romano, depois de Marco-Aurélio, em lugar de reducir á escravidao os povos vencidos $(\ldots) \cdot .^{12}$

Una de las razones por las que se hace posible la explotación de las vegas es la existencia de fortificaciones vigía a lo largo del curso de río. En el caso de la vega del Tajo en el tramo estudiado, la protección y vigilancia se daba gracias a la fortificación situada en la actualidad en el término municipal de Malpica de Tajo, frente al actual castillo y en el margen derecho del río.

Es tradición romana el reparto de tierras entre los soldados: el objetivo principal es la colonización y entrada en producción de los espacios conquistados así como el mantenimiento y control de las vías de comunicación. Aparece así la arquitectura de colonización y se intensifican los tres cultivos mediterráneos por excelencia: cereal, vid y olivo. ${ }^{13}$

La calzada, en este caso la que unía Caesaróbriga -Talavera de la Reina- con Toletum Toledo-, garantiza la comercialización de las abundantes cosechas y del ganado. Se genera una economía que evoluciona hacia el comercio internacional frente a la economía de subsistencia precedente.

\footnotetext{
12 De Sousa/Tôrres, 1946: 126.

${ }^{13}$ Palomeque, 1956.
} 


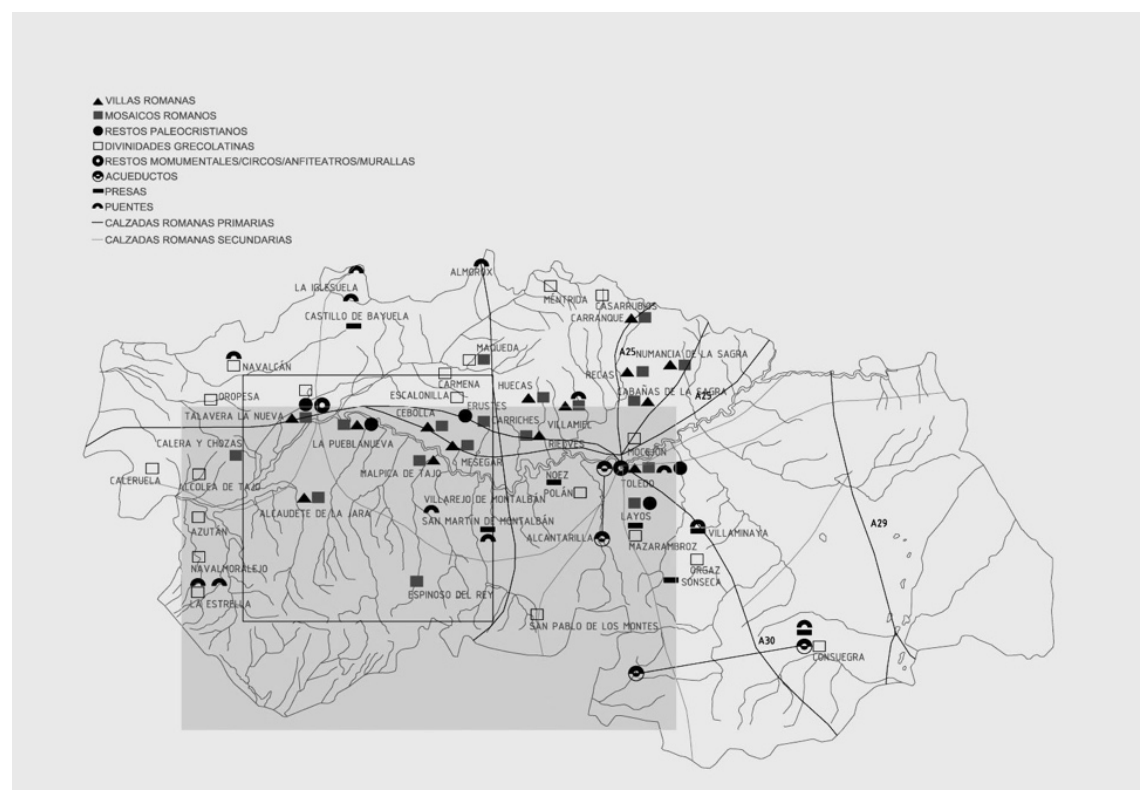

Fig. 7. Mapa de restos romanos en la provincia de Toledo. Fuente: la autora.

"El tipo de construcción aislada en el campo, desconocida por los pueblos primitivos, fue de importación romana, y tuvo un gran relieve en la historia económica y social como centro de los inmensos dominios rurales privados saltus que tanto influyeron en el profundo cambio que supuso la economía agraria durante el Bajo Imperio (...). El campo de ruinas queda a unos 500 metros de la Casa de Labranza actual". ${ }^{14}$

"Además, el territorio toledano, y especialmente la rica vega del Tajo, se encontraba bien poblado de fincas destinadas al uso y disfrute de grandes latifundios, villas como El Saucedo -Talavera la Nueva- Las Tamujas -Malpica de Tajo-, Santa María de Abajo-Rielves- o el mausoleo de Santa María de las Albueras - la Pueblanueva- constatan la existencia de una importante clase aristocrática provincial que no durará en fundirse con la advenediza goda (...). La aparición de un importante lote de sarcófagos paleocristianos habla también a favor de la existencia de una potente clase adinerada que podía demandar ese tipo de artículos de lujo". ${ }^{15}$

Junto con la aparición de las grandes fincas como concepto, la civilización romana delata su presencia a través de otro tipo de construcciones como las infraestructuras relacionadas con el almacenamiento y transporte del agua. En San Martín de Montalbán, en los alrededores de la posteriormente construida ermita de Sta. María de Melque, ${ }^{16}$ se encuentran los restos de varias presas.

Mientras todo esto ocurre en la vega, la llanura aún no ha sido roturada y los montes quedan sin colonizar. Quedando relegados a su labor defensiva frente a ataques provenientes del sur y convirtiéndose en zona de vigía, de caza y de escondite.

\footnotetext{
${ }^{14}$ Ibídem, 1959.

${ }^{15}$ Barroso/Garrobles/Morán, 2011.

${ }^{16}$ Con respecto a la cronología de Melque, se pueden encontrar diferentes hipótesis de datación: (Ruiz Souza, s.VI /Garen s. VIII/ Caballero Zoreda s. IX).
} 
Fig. 8. Estudio comparativo del reparto de programa de necesidades en planta. Villa Settefinestre y Finca Casablanca, Montearagón, Toledo. $350 \mathrm{~m}$. de altitud. Fuente: la autora.
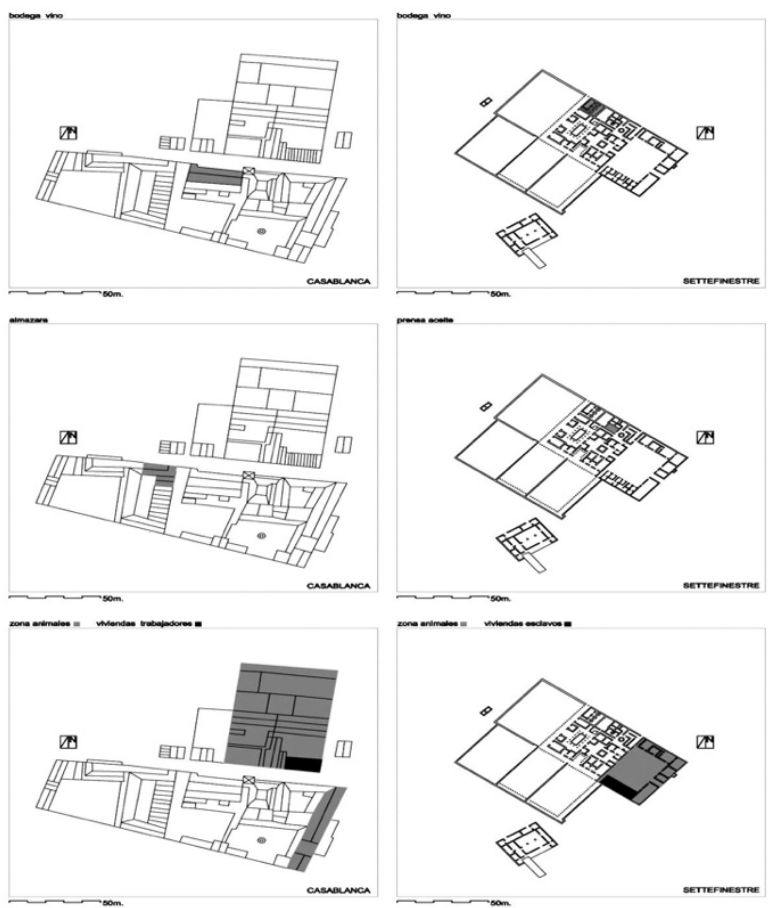

Con la caída del imperio y la llegada de los visigodos, se olvida el comercio a gran escala $y$, a pesar de mantenerse una estructura territorial similar, se reducen los intercambios de información, oficios y material propios del Imperio Romano.

"La crisis económica de los últimos tiempos del paso de la dominación romana a la visigoda, debió favorecer la tendencia de estas villas a dibujarse como círculos de economía doméstica casi cerrada, siendo esta organización la que, a través de la monarquías germánicas, sería heredada por la sociedad medieval europea (...). Posiblemente, de la dominación romana a la visigoda se pasó sin grandes alteraciones en esta comarca de la meseta y la Villa, aunque pudo ser más o menos saqueada, no fue destruida (...) como en el valle del Tajo debieron asentarse bastantes germanos, como lo confirma la necrópolis del Carpio de Tajo."

"La arquitectura rústica visigoda tiene idénticos tipos que la romana y también extensas posesiones agrícolas pertenecientes a un señor y otras modestas agrupadas en Vicus+Villa Tertia+Iglesia o capilla" ${ }^{17}$

Los germanos, en su distribución por las tierras dominadas en nuestra geografía, vivieron en estrecho contacto y en convivencia con los pobladores provinciales hispanorromanos que serán los encargados de prorrogar la vida de las antiguas villas. Éstas pasarán a transformarse de Villa romana a Vicus visigoda en el inicio de un recorrido que llevará hasta la casa de labranza actual.

"En cuanto a Melque, los últimos hallazgos llevan a Luis Caballero y su equipo a plantear la idea de un monasterio implantado en época visigoda sobre un asentamiento romano rural y minero que en el momento de implantación del estado islámico en la península

\footnotetext{
${ }^{17}$ Palomeque, 1959.
} 


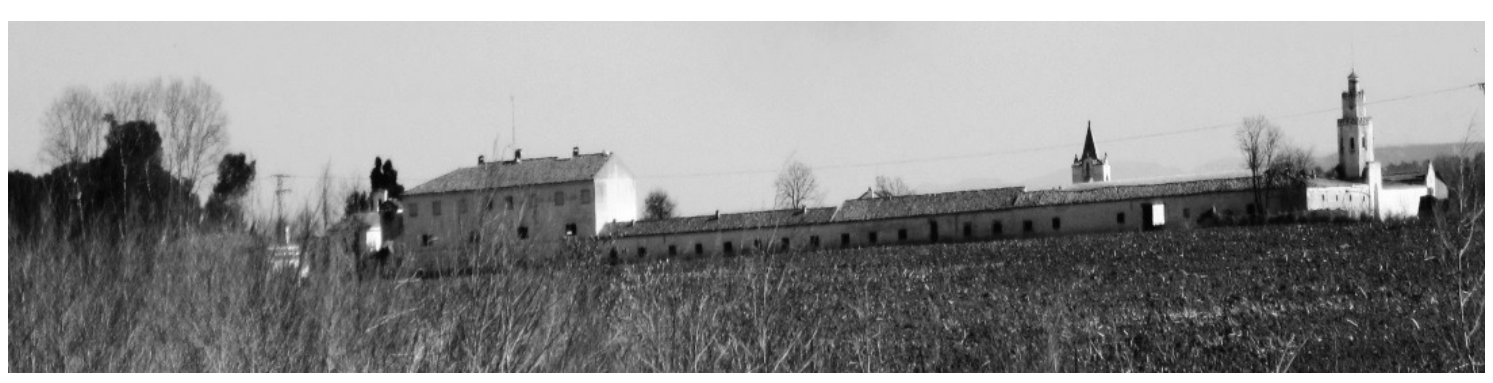

Fig. 9. Imagen actual de Edificación de uso agricola y ganadero en la Vega del Tajo, Montearagón, $320 \mathrm{~m}$. de Altitud. Fuente: la autora.

sigue utilizando propiedad y mano de obra visigodas, pero implantando tecnología de explotación musulmana (...). Por otra parte, debemos tener en cuenta que el auge de los estudios sobre la Antigüedad Tardía ha llevado a plantear un reposicionamiento cronológico que trasciende los esquemas de ruptura tras la crisis bajo-imperial los estudios basados en los elementos aportados por la cultura germánica, importantes pero no únicos, sobre todo en las zonas rurales (...) de los siglos IV-V al VIII, que asume cierta continuidad de formas materiales a pesar de los cambios políticos". ${ }^{18}$

El Toledo visigodo se concentra en un inicio en la capital, Toledo, mientras en el ámbito rural conviven con los indígenas hispanorromanos. "Como la Jara y los Montes, por sus especiales condiciones geográficas, la población siempre fue escasa y la repoblación tardía (...) la situación socioeconómica apenas se modificó tras el asentamiento de los visigodos. Éstos se integraron en las estructuras feudalizantes del Bajo Imperio sin apenas aportar ninguna novedad (...). En el s. VII ya hay una importante comunidad judía en Toledo capital". ${ }^{19}$ El núcleo central de la población visigoda será Toledo. En el ámbito rural se dará una convivencia estrecha entre los habitantes hispanorromanos y los nuevos colonizadores que, en muchos casos, llegarían después de mucho tiempo a los enclaves de menor accesibilidad tales como la mayor parte de los municipios que se encuentran en los montes. De esta forma poca sería la evolución desde los tiempos de los Carpetanos más allá de la vega, por no haber llegado la invasión en términos prácticos ni romana ni visigoda hasta esas altitudes. Sin cambios políticos o culturales es difícil que se diera una evolución significativa en las soluciones constructivas salvo las que fueran producto de la mejora evolutiva con el tiempo de soluciones con el mismo origen.

En lo que respecta a las villas del cauce del río Tajo, pasan directamente de la élite romana a la élite visigoda lo que supondría leves transformaciones tanto en el modo de reparto del territorio, que seguiría siendo latifundista en esa altitud, como en la tecnología y tipo de cultivos. Sin una evolución en el entendimiento del territorio ni en su reparto, es difícil que se iniciara la construcción de nuevas edificaciones ligadas a la explotación sino, más bien, que se adoptaran como válidas y se reconstruyeran las ya existentes durante la dominación romana.

"Unos 200.000 visigodos se asentaron al norte del Tajo. Unas 1.500 familias nobles se dispersan para controlar el total del territorio (...). La situación socioeconómica apenas se modificó tras el asentamiento de los visigodos. Estos se integraron en las estructuras feudalizantes del Bajo Imperio, sin apenas aportar ninguna novedad". 20

La comunidad judía, asentada desde el s. VI en Toledo, tendrá una importante influencia en la configuración del territorio de los Montes de Toledo, dependientes en su mayoría de la

\footnotetext{
${ }_{18}^{18}$ II Congreso Arqueología Provincia Toledo, 2001:338-339.

${ }^{19}$ Izquierdo, 1985.

${ }^{20}$ Izquierdo, 1985: 5-11.
} 


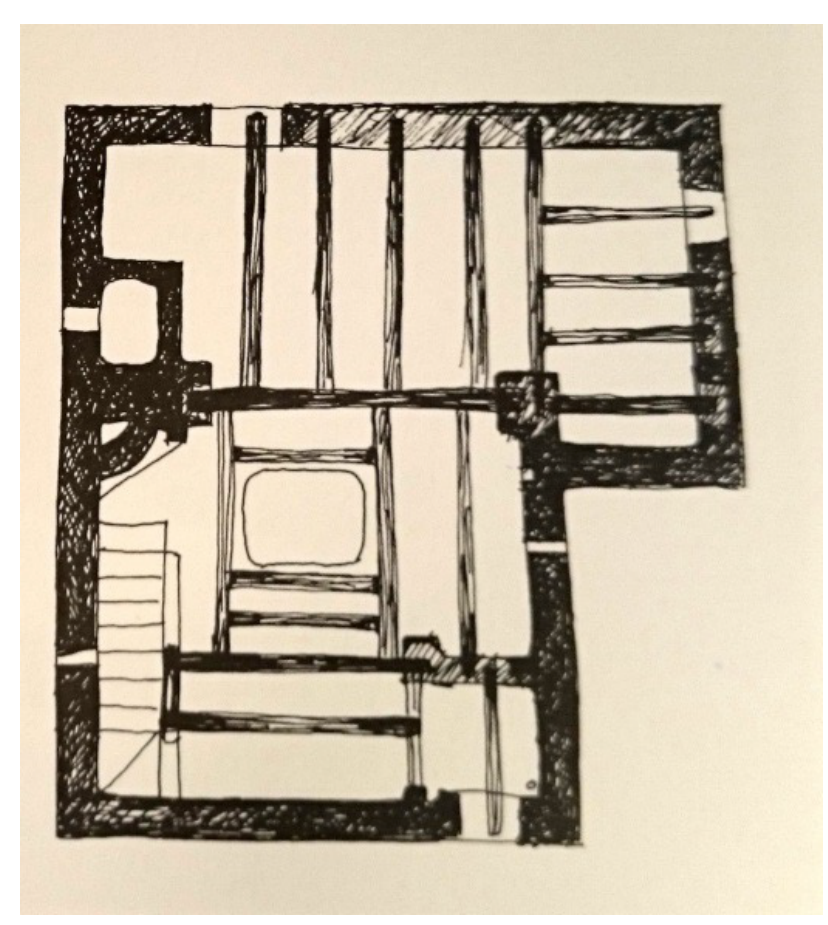

Fig.10. Solución estructural de un cambio de dirección en la cubrición de espacios con cubierta plana en el M'Zab, Argelia. Fuente: Ravereau (1981).

capital. Durante la permanencia de los judíos, no se producirá prácticamente roturación de los montes; la cordillera y la falda norte hasta bien entrada la llanura, permanecerán sin cultivos destinándose a la explotación cinegética únicamente.

Esta decisión fue una decisión de rentabilidad económica debido a la escasa pluviometría de la zona y a la composición de los terrenos, principalmente arcillosa salvo en la cuenca del río Cedena. Esta filosofía de explotación económica del territorio se verá truncada con la expulsión de los judíos en el s. XV, así como las desamortizaciones de siglos posteriores y el inicio de roturación de la llanura de secano y de los montes. La roturación generaría una economía de subsistencia que florecería únicamente a finales del s. XIX-inicios del s. XX con la valorización del aceite de oliva que, tras ensayos durante siglos de cultivo de cereal, sequías, hambrunas e inundaciones, se convertirían en el cultivo por excelencia en la zona.

"A partir del s. VIII una nueva configuración territorial se iba a desarrollar, terminando con las antiguas demarcaciones administrativas romanas mantenidas por los visigodos, que vendría muy marcada también por el asentamiento que los musulmanes realizaron en distintas zonas para asegurar el dominio del territorio (...). En las riberas del Tajo se asentaron miembros de las tribus Bahila y Kinanies. Al sur de Toledo los Bereberizados con las tribus Nafza, Miknasa, Kutama y Hawwara". 21

Con la llegada del s. VIII y el inicio de las conquistas por parte de los pueblos musulmanes, dará comienzo una época de fuertes cambios que persistirán hasta casi el final de la Edad Media. La fuerte presencia berebere, dejará su impronta en la trama urbana de la ciudad de Toledo y de los cascos urbanos de toda la provincia así como en el entendimiento del reparto de la tierra y en la configuración de la arquitectura doméstica. También en la concepción de las edificaciones y en el abundante uso del tapial como

${ }^{21}$ Ibídem. 

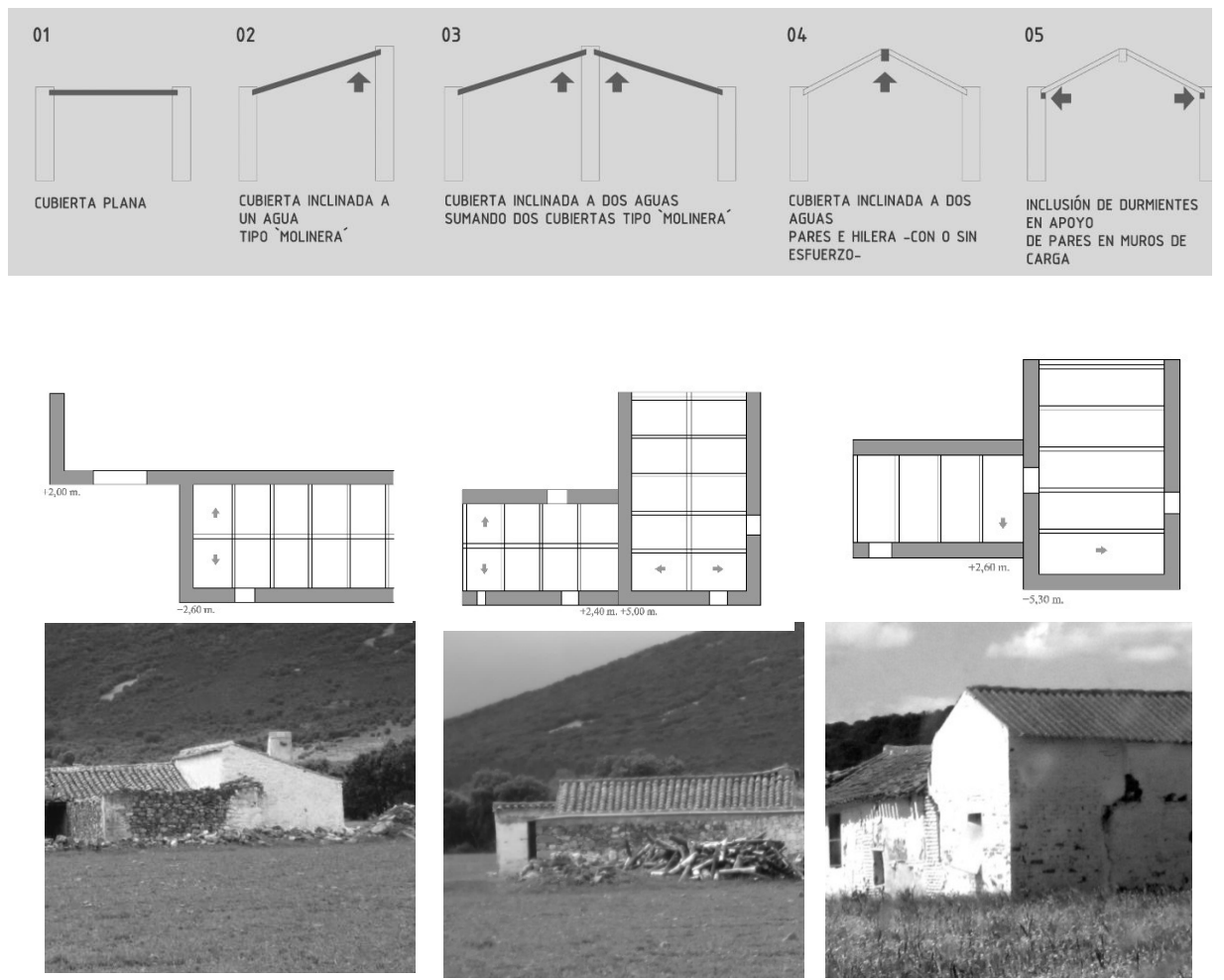

Fig. 11. Soluciones volumétricas para el cambio de dirección en la cubrición de espacios con cubierta inclinada. Y evolución desde cubierta plana a inclinada de par e hilera. Edificaciones ligadas a agricultura y ganadería en los Montes de Toledo. Términos municipales de San Martín de Pusa, y Navahermosa, Toledo. Fuente: la autora.

solución constructiva. Aclimatados a un territorio con una pluviometría mucho mayor que la de su tierra de origen,

desaparece la azotea y con ella la escalera de acceso desde planta baja. La configuración de viviendas en las estribaciones comenzará su andadura de crisis geométrica permanente entre geometría irregular de planta y encuentros de faldones de cubierta inclinada. El paso de una arquitectura de cubierta plana a una arquitectura de cubierta inclinada presentará dificultades de entendimiento de la geometría de estructuras de sustentación de más cubiertas a más de dos aguas que se prolongarán hasta la actualidad. La arquitectura vernácula de los montes de Toledo hasta la Vega evitará en casi todos los casos las cubiertas a más de dos aguas por requerir de un conocimiento más preciso del funcionamiento de las estructuras inclinadas de madera. Las soluciones dadas a cubiertas con más de 2 aguas en la llanura adolecerán de ese desconocimiento y se resolverán en la mayor parte de los casos con grandes carencias técnicas.

"La invasión musulmana traerá consigo un sistema de gobierno que afecta a la nobleza territorial, basado en el pacto con esas clases dirigentes de la población visigoda para la implantación de un nuevo sistema impositivo, junto al asentamiento de los nuevos colonos en tierras confiscadas (...). Todo esto justificaría una cierta continuidad cultural, por una parte, y el baile cronológico a que nos llevan en muchos casos las cartas 
arqueológicas (...)".22 En estudios realizados en grandes fincas en Andalucía, se sostiene que se dio continuidad a las explotaciones durante la invasión musulmana y que el único período de inactividad se correspondería con las guerras conquistadoras cristianas. ${ }^{23}$

El paso de los Montes de Toledo, que ya era paso natural hacia el sur en época romana, lo seguirá siendo en época visigoda y durante la reconquista. La marca media, en la que se convertirá Toledo durante siglos, forzará a gran parte de la población a la reubicación desde la vega, más vulnerable, hacia los montes. "El vocablo Yébenes es una degeneración del Yebel árabe, que significa monte (...). Ya en la época romana este paso es frecuentado y lo mismo en la Reconquista". ${ }^{24}$

Los aborígenes durante el inicio de la invasión musulmana eran mayoritarios y se dividían en dos grupos: los Muladíes -hispano-visigodos convertidos al islamismo-, y Mozárabes cristianos toledanos denominados así por los musulmanes-. La zona del Tajo se convierte en frontera con una fuerte militarización de la región y presencia de recintos fortificados de cara a la defensa frente a los cristianos del norte. En Toledo se generará la frontera denominada Marca Media. "Hay que pensar que la población hispano-romana continúa viviendo en el territorio a lo largo de la dominación musulmana, ya como mozárabes; así continuaron después de recuperado el país por los reconquistadores castellanos $(\ldots)$ ". ${ }^{25}$

En el 741 Los bereberes del sur de Toledo son derrotados en una rebelión y se arabizan rápidamente. Comenzará entonces la primera época convulsa que entre el 768 y el 797 se materializará en un Toledo-estado independiente poblado por una mayoría de aborígenes que no iban a aceptar las imposiciones de las autoridades extranjeras dando lugar a frecuentes revueltas.

En el 829 Hashim asaltará caminos viajeros de las vías de la provincia consiguiendo que se unieran a él los campesinos de la Vega del Tajo, muriendo dos años más tarde a manos del ejército cordobés. En el 888 Toledo sería tomado por la suma de fuerzas de un bereber llamado Musa que entraría en contacto con un toledano de nombre Lope Ben Tarbisha.

En los años posteriores comenzará la época del califato siendo invadido Toledo por Abd Al Rahman e iniciándose un proceso de arabización y trasladándose la Marca Media, o frontera, de Toledo a Medinaceli. A partir de ese momento toda la actual Castilla la Mancha sería zona agrícola con cultivos de cereales y hortícolas. Se introducirían las acequias y las norias a lo largo de la cuenca del Tajo.

"No sabemos si se mantuvo el sistema latifundista de época visigoda, si desapareció o disminuyó por los repartos de tierras llevados a cabo por los musulmanes. Si se ha constatado la existencia de grandes fincas agrícolas en tierras de Toledo productoras de cereales y de minas en los Montes de Toledo (...) la vía Mérida-Toledo, a través del Valle del Tajo, era zona de comunicación del comercio". ${ }^{26}$

El caso de la falda Norte de los Montes de Toledo, con su especial orografía, sigue siendo el de una tierra escasamente poblada. En el caso de la aparición de núcleos urbanos, éstos serían de pequeño tamaño, cercanos los unos a los otros, y casi exclusivamente dedicados a tareas agrícolas. Ese tipo de configuración territorial se mantiene en la zona comprendida entre Santa Ana de Pusa y Alcaudete de la Jara hacia los Montes, donde abundan pequeños municipios relativamente cercanos y donde, de manera intensa, se ha dado la explotación de cultivos hortícolas, la profusión de huertas a lo largo de los afluentes del Tajo y la implantación de pozos y norias.

"La zona del valle del Tajo, por sus grandes posibilidades agrícolas, ya desde época musulmana estuvo bastante poblada. La población se concentraba en pequeñas aldeas,

\footnotetext{
22 II Congreso Arqueología Provincia de Toledo, Vol. I: 339.

${ }^{23}$ Halcón, 2002.

${ }^{24}$ Jiménez de Gregorio, 1966: 253.

${ }^{25}$ Ibídem: 308-309.

${ }^{26}$ Izquierdo, 1985:14-24.
} 


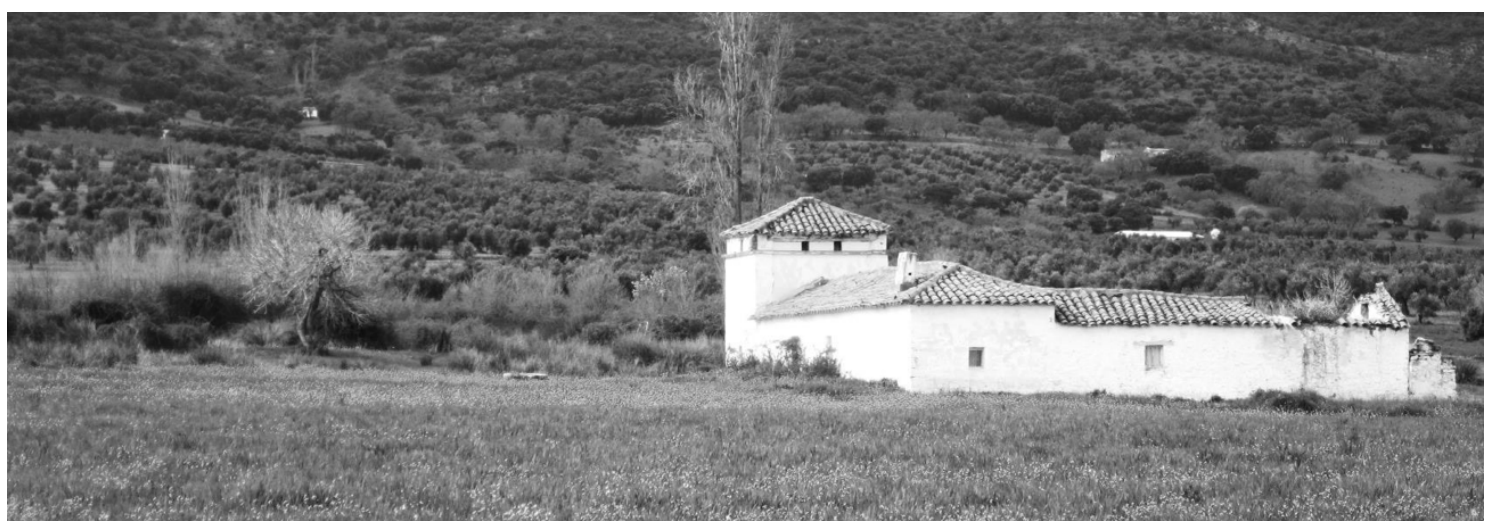

Fig. 12. Casa de labranza en las estribaciones, Término municipal de Navahermosa a $650 \mathrm{~m}$. de Altitud. Fuente: la autora.

muchas de las cuales desaparecieron tras la llegada de los cristianos; otras muchas continuaron perdurando hasta nuestros días (...) presentando un paisaje agrario con núcleos habitados no muy grandes relativamente próximos unos a otros (...) como la Jara y los Montes, por sus especiales condiciones geográficas, la población siempre fue escasa y la repoblación tardía". ${ }^{27}$

“(...) poner en práctica un proceso colonizador, asentando campesinos o pastores en aquellos lugares que presentasen mayores posibilidades estratégicas y/o económicas (...) los mozárabes mantienen e incrementan sus propiedades tras la llegada de los cristianos (...) parte de ellos marcharán en el futuro a repoblar otros territorios. Así se pasaría en la zona de una propiedad de población libre y minifundista a latifundista de terratenientes asentados en la ciudad y utilizando ésta naciendo un régimen feudal". ${ }^{28}$

Desaparecerán las comunidades rurales mozárabes entre los siglos XII-XIII. Entre los despoblados de esta época destacan el de Melque en el T.M. de San Martín de Montalbán y el de Los Vascos, ${ }^{29}$ en el T.M. de Navalmoralejo.

La información más detallada sobre la existencia de casas de labranza con su toponimia, situación y área de trabajo se encuentran mejor definidas en las relaciones de Felipe II y en las del Cardenal Lorenzana además de en el Catastro de la Ensenada. Pero se dan con anterioridad descripciones, con motivo de ventas o traspasos, de Casas de labranza y tipo de explotación correspondientes al s. XII como las recogidas por Jiménez de Gregorio en su descripción histórica de los pueblos de Toledo. Este es uno de los datos que arroja algo de luz sobre el origen de las casas de labranza de tamaño medio que se desarrollaron en su mayoría durante la Edad Media. Se concentran entre las estribaciones de los montes y la llanura. Estas explotaciones tendrán un tamaño intermedio entre las grandes fincas, que se han ido transfiriendo las familias más influyentes de las distintas civilizaciones, y las persistencias indígenas de los montes.

"En diciembre de 1149 se habla de la venta de una labranza en la alquería de Rielves, llamada villa Ansía, con sus casas, eras, huertos y tierras. Tal vez se trate de un villar o villa hispano-romano. En el 1150 se menciona de nuevo esa labranza (...) ya en 1290 se habla de los palomares que hay en esta tierra de Rielves y sus cercanías". 30

Estas casas de labranza, aisladas y en principio desprotegidas, se verán positivamente afectadas por las distintas fortificaciones que, en época de reconquista, se iban a diseminar

\footnotetext{
${ }^{27}$ Izquierdo, 1985:85.

${ }^{28}$ Ibídem: 37.

${ }^{29}$ Izquierdo, 2005.

${ }^{30}$ Jiménez de Gregorio, 1966: 308-309.
} 
por el territorio. Es precisamente esa situación la que permite su supervivencia y su crecimiento como nueva forma de explotación de tierras roturadas. No disponían del agua y las ricas tierras de la vega pero que tampoco sufrían la inaccesibilidad de las tierras altas del monte. Su topografía permitiría el cultivo de cereales en secano y se ubicarían siempre cercanas al curso de un río -afluente del Tajo- o a un pozo.

"La fortaleza de Dos Hermanas, la Torre de Mala Moneda, Cedenilla y la villa-castillo de Montalbán, que pertenecían a la jurisdicción señorial de Alonso Téllez de Meneses, formaban una barrera defensivo en las asperezas de un territorio que después colonizarían los toledanos, al formar parte de sus montes". ${ }^{31}$

La historia que liga los montes a la ciudad de Toledo se iniciará en el año 1243 con la venta por parte del Rey Fernando III a la ciudad de Toledo de toda la comarca que se describe como semidespoblada. “(...) trueque que se llevó a efecto en virtud de la escritura firmada en Valladolid, fecha 20 de abril de 1243. Pocos años más tarde, teniendo el Santo Rey necesidad de numerario para preparar la empresa conquistadora contra Sevilla, no dudó en vender esta agreste comarca semidespoblada a la ciudad de Toledo (...)".32

"Que el Ayuntamiento toledano es `Dueño y Señor de los lugares que se llaman propios y montes de Toledo y sus términos y sus despoblados con la jurisdicción civil y criminal alta y baja y mero mixto imperio en todos ellos (...) sobre el conocimiento de causas y delitos criminales que acaecen en los despoblados' (...) se da a entender que desde el momento en que se produjo la compra de los dichos lugares a Fernando III comenzó Toledo a ejercer su jurisdicción a través de su fiel del juzgado (...)". ${ }^{33}$

A partir de ese momento comenzará la roturación de llanura y estribaciones de forma mucho más intensa tras las continuas reclamaciones de los campesinos a la ciudad de Toledo. Eran todas ellas reclamaciones destinadas a la mera subsistencia que se veía mermada por los tributos anuales a pagar a la ciudad por cada cosecha "ordenando a los alcaldes de su jurisdicción la confección de censos ganaderos, autorizando a los pueblos para que se venda o se preste a los labradores trigo de la cilla 'porque no tienen qué sembrar', permitiéndoles vender o arrendar la cosecha de bellota de los encinares comunales así como las tierras recién roturadas o prohibiéndoles todo género de caza ‘en los tiempos y meses vedados"”.

Se trata de otro momento de expansión de la figura de la casa de labranza que abunda en la actualidad en la zona intermedia entre montes y vega. El cultivo del cereal en extensiones de tamaño medio, obliga a la construcción de edificaciones en las que pernoctar, guardar la ganadería mayor que forma parte de la fuerza de trabajo y trillar y almacenar la cosecha. Para después transportarla a los núcleos urbanos y, en parte, a la ciudad como tributo.

"de dos en dos años los moradaroes della elegian entre si seis personas, a quien llamauan Fieles, los tres
dellos del estado de los cavalleros, y otros tres de los ciudadanos. Todos seis juntamente con dos Alcaldes
el uno Castellano y el otro Muzarabe, y con el Alguazil mayor, tenia cargo principal del regimiento de
la ciudad. Y para que una cosas de las que ordenauan passasse por Ayuntamiento, era menester que
todos, o la mayor parte de ellos fuesen conformes (...) hasta que Afonso XI (1312-1350) con sus
disposiciones contribuyese a la suplantación legal de los concejos de muchas ciudades
por el sistema del Regimiento y, más bien, en nuestro caso, hasta que Juan II expidiese
en Toledo en 1422 el privilegio creando los regidores y jurados, base de su nueva
organización municipal (...."..35

El conjunto de municipios que irán apareciendo y tomando forma con las nuevas roturaciones y como resultado de la unión de múltiples casas de labranza, comenzarán a tener mayor libertad de gobierno con Alfonso XI en el s. XIV ya que su sistema de Regimiento daría una cierta libertad de actuación a los diferentes municipios que contarán con nuevas

\footnotetext{
${ }^{31}$ Barroso/Garrobles/Morán, 2011.

${ }^{32}$ Palomeque, 1954: 5.

${ }^{33}$ Palomeque, 1972: 323-325.

${ }^{34}$ Ibídem, 1954:9.

${ }^{35}$ Ibídem, 1972: 325.
} 


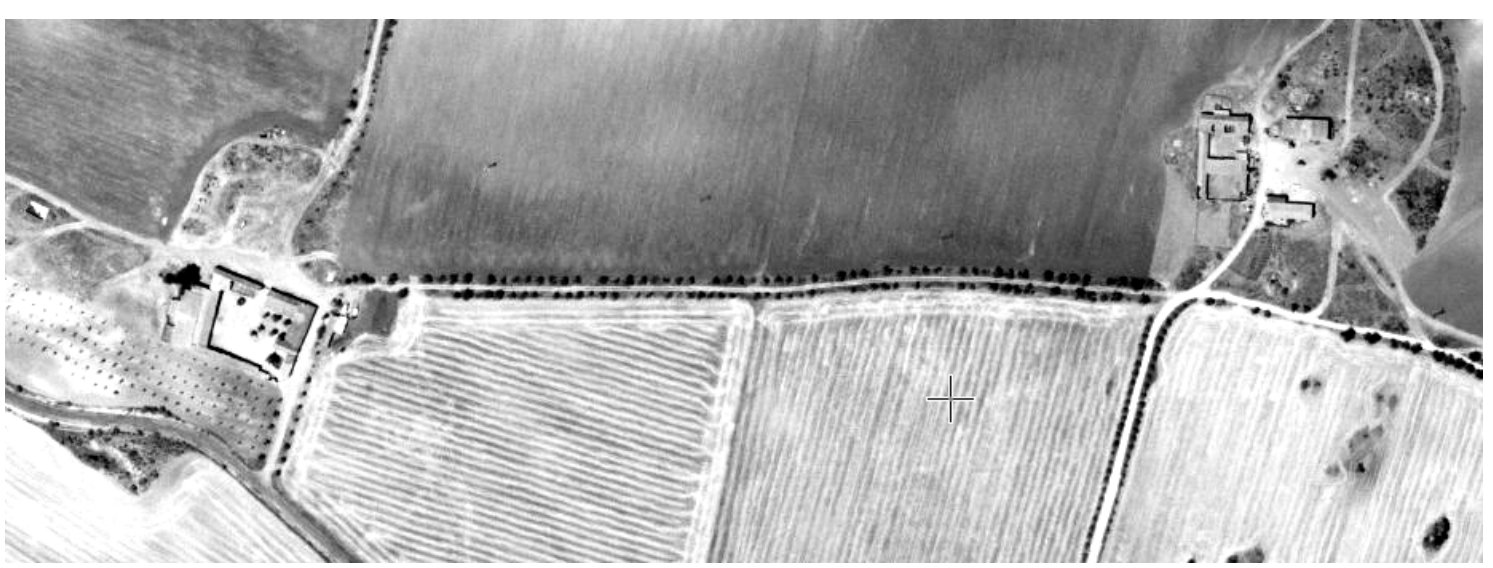

Fig. 13. Imagen de satélite de casas de labranza en secano en el T.M. de Polán, a $540 \mathrm{~m}$. de Altitud Fuente: http://sigpac.mapa.es/fega/visor/

bases de organización municipal cuyo núcleo será el concejo. Surgirán así nuevas relaciones entre los nuevos municipios, una consolidación de la organización del territorio en la que aparecerán los bienes comunales, y sistemas de protección de las explotaciones más aisladas. Surgirá la Santa Hermandad de los Montes de Toledo que dará protección a las casas de labranza frente a los Golfines instalados en las zonas más inaccesibles de los Montes de Toledo. Nuevamente, un tiempo de estabilidad comienza con la reconquista y con él el desarrollo de un formato de explotación y colonización del territorio que se mantendrá hasta nuestros días en la llanura y las estribaciones. En la vega, en cambio, las grandes fincas irán pasando de nuevo a manos de familias nobles o de órdenes eclesiásticas. Se irán desarrollando los diferentes señoríos a los que se deberán los habitantes de la zona. Los señoríos deberán la base de su subsistencia no tanto a los tributos de los campesinos como a la posesión de las fincas de mayor producción; los regadíos de la vega.

“(...) de todo esto gozaron libremente los vecinos toledanos durante más de 200 años hasta que en 1446 el rey Juan II hizo merced de esta tierra (...) formaban parte de la tierra cedida (...). La Puebal, Herrer, Fuenlabrada, Villharta y Helechosa (...) la ciudad quedó con el señorío de lo que venía llamándose Montes de Toledo (...). Muy útil y necesaria que llamaban la Hermandad Vieja de que son hermanos todos los que tienen hacienda de colmenas en los montes de la ciudad (...) La Vieja, que poseía cárcel propia, dice que fue fundada por los mismos pueblos de los montes y después confirmada y privilegiada por los Reyes. Sólo existía en Toledo, ciudad Real y la Villa de Talavera. (...) esta Santa Hermandad iba dirigido contra ciertos ladrones llamados Golfines que infestaban la comarca robando y matando, haciéndose fuertes en los montes ásperos en los que era difícil penetrar (...). Después de tratar el historiador toledano del nombramiento del Alcalde de la Mesta (de los pastores y señores del ganado)". ${ }^{36}$

"Pocos años más tarde, el 9 de Junio de 1500, los Reyes Católicos otorgaban en Sevilla la pragmática conteniendo los capítulos y ordenanzas que deberían guardar los asistentes, gobernadores y corregidores de las ciudades, villas y lugares de sus reinos y señoríos, instrucciones con las que quedaban reguladas las funciones del pieza esencial y la más característica en la administración centralizada de la monarquía autoritaria y absoluta". ${ }^{37}$ Otra de las razones de la proliferación de las roturaciones durante el tiempo posterior a 1.400 será la expulsión de los judíos de la ciudad de Toledo. En 1492 desaparecerá una visión particular de la explotación de los montes basada en los recursos cinegéticos. A partir de ese momento

\footnotetext{
${ }^{36}$ Palomeque, 1972: 33.

${ }^{37}$ Ibídem: 331.
} 
comenzará la explotación agrícola de unas tierras intermedias de poca rentabilidad que se convertirán aun así en la base de la subsistencia de la mayor parte de los pobladores de la zona. Esa baja calidad de las tierras traerá consigo una prolongada pobreza de los pobladores que hará que la Edad Media, con sus soluciones y tipos constructivos y con sus formas de vida, se extienda hasta bien entrado el s. XX.

"La deposición de los conversos tuvo, como decimos, honda repercusión en la historia social y religiosa del siglo XV y aún de los siguientes. Pero, entre las consecuencias inmediatas que podemos estimar relacionadas directamente con él, están los sangrientos sucesos desencadenados en el propio mes de Junio de 1449 entre cristianos viejos y confesos (...). Lo que se planteaba aquí era precisamente, como en Toledo, la disputa por la posesión de las escribanías públicas, que se decían compradas por los judaizantes o cristianos nuevos, los cuales fueron arrollados por la reacción que en su contra se levantó". ${ }^{38}$ Toledo capital, en cambio, alcanzará su máximo esplendor en el s. XVI pero también su máxima caída con el traslado de la corte de Felipe II a Madrid. La historia del débito de la ciudad de Toledo con el clero comienza justo en ese momento prolongándose hasta la actualidad.

“Toledo 1560 que como era cabeza de España podía serlo en aquel tiempo de toda Europa; pero en la segunda mitad de este siglo XVI, con el traslado de la Corte de Felipe II a Madrid, se la desposeyó en la práctica de la capitalidad, iniciándose a partir de entonces un largo período de decadencia viéndose obligada a acogerse al amparo del poder eclesiástico que, en adelante, sería su único sostén `madre, mecenas, faro y guía". 39

Algunos de los textos que nos dan algo más de información acerca del reparto del territorio y las formas de vida de la zona serán los informes de los visitadores del concejo toledano, que tendrán por objetivo el control anual de la producción en las tierras que les deben tributo. En ellos se recogen los tipos de cultivo. En el s. XVI aún la vid ocupa más extensión que el olivo. Es precisamente la ausencia de tributo de este cultivo lo que generará en los siglos posteriores su proliferación en todos los Montes de Toledo.

"En vista del informe de los visitadores el concejo toledano aprobó una serie de disposiciones. En primer lugar antes la queja de los vasallos de recibir agravio a causa de que las visitas de los fieles del juzgado solían hacerse en agosto, época en la se encontraban muy ocupados 'en el coger de sus panes' y no podían acudir a sus llamamientos so pena de dejar abandonada la recolección del cereal (...) que la ciudad haga un concierto de todas las que tuviese cada oficial por cinco blancas y así mismo, otras tantas las medidas de vino y aceite según viene acostumbrando la ciudad". ${ }^{40}$

Las descripciones informan además sobre la ganadería; en su mayor parte menor. La ganadería mayor es la de la fuerza de trabajo. La apicultura es también una de las tareas más abundantes sobre todo en las estribaciones donde los terrenos no permiten otra explotación y donde son abundantes las plantas aromáticas. Los huertos se extienden a lo largo de las vegas de todos los afluentes y en ellos continuará hasta el s. XX el uso de las norias, implantadas con la llegada de los pueblos musulmanes.

“(...) a señalar e señalen los ganados que les vienen de dicho dozauo, al comenzar cada año, y una vez señalados, el labrador tuviese la obligación de guardarles hasta el día de Todos los Santos del siguiente año (...) disponiendo que de doce potricos, otros tantos borricos o becerros se debe pagar uno; si sólo fuesen seis abonaría medio, y si no llegaran a seis pagaría una determinada cantidad de maravedís según la clase de ganado (...). Por una colmena vieja, una blanca (...). De doce enjambre, otra blanca y seis y media y, en cuanto a corderos y chivos, también de doce se debía entregar uno y de seis, medio (...). En cuanto al pan se disponía (...) llevándose de doce fanegas, una. Anteriormente todos los labradores deberían depositar todo el cereal (pan) que cosecharan en la cilla (cámara o casa donde se recogían los granos) (...). Los huertos

\footnotetext{
${ }^{38}$ Benito, 1965: 49-50.

${ }^{39}$ Palomeque, 1972: 336.

${ }^{40}$ Ibídem: 336-337.
} 
que sólo tuviesen una media aranzada de tierra (medida agraria castellana equivalente a unas 447 deciáreas) quedaban exentos de pagar el dozavo de los frutos que allí se recogiesen excepto si se trataba de cáñamo, lino e pan segado". ${ }^{41}$

“(...) solicitar del de la ciudad de Toledo y del marqués de Malpica 'licencia para que el ganado vacuno de entrambos lugares puedan andar juntos, gozar y pastar', suplicándoles intentasen llegar entre ellos a una concordia que condujera a tener pastos y guardia común, pues de no llegar el poco ganado, ya en disminución, tendría que seguir vendiéndose (...). Entre los menos dañosos que proponían figuraban el de `poder arar y romper un pedazo de tierra suya' que tienen tanto junto al lugar, de unas doce fanegas de extensión, para poderle sembrar; el de ser autorizados para vender `la oja de sus viñas por tiempo de seis años' y el de podar un chaparral de su propiedad y vender la leña en rama, transformada en carbón, ’o como mejor convenga'(...) poda del chaparral, roturación de nuevas tierras, corte de hojas de viñas viejas $(. .). " .{ }^{42}$

El s. XV será también el siglo de la huida de judíos desde la capital hasta las zonas más recónditas de los montes. Se inicia así una nueva y particular repoblación que tendrá como herederos a algunos de los municipios de las estribaciones una vez superada la memoria de la expulsión.

"Ya con la ocasión de la incapacitación para cargos públicos a los conversos que pretendió establecer perpetuamente la Sentencia-Estatuto de Pero Sarmiento, vimos las respuestas pontificas contrarias de 24 de Septiembre de 1449. En ellas (...) quedan condenados expresamente y por igual el delito de rebelión de Toledo y el principio de desigualdad entre cristianos sentado por dicho documento". ${ }^{43}$ Lo bienes comunales, que habrían de desaparecer casi en su totalidad con las desamortizaciones del s. XIX, se describen hacia 1500 y formarán parte de un sistema de compensación de carencias de los habitantes del territorio que favorecerá enormemente su subsistencia. “(...) en nombre de la justicia y regimiento del lugar de Navalmorales de la parte de Toledo, para exponerle que en este último lugar existen algunos prados y arroyos utilizados por el concejo para que en ellos pudiesen pastar solamente el ganado, pero `no el de cerda ni otro alguno $(\ldots)^{\prime \prime \prime} .44$

De los s. XVII y XVIII la información disponible es la de largos períodos de hambruna en toda la zona por la escasa producción agrícola debida a la falta de lluvias en otoño y a las inundaciones en primavera. La subida de los precios en las lonjas de cereal y la proliferación de enfermedades en las zonas inundadas dan como resultado un paisaje bastante desolador y en proceso de empobrecimiento paralelo al del Estado. En estudios realizados en Andalucía sobre las grandes fincas de la campiña cordobesa, se afirma el papel de las mismas como demostrador de poder económico y político por parte de la nobleza desde la apertura del mercado americano. Surgirían en el s. XVII ornamentaciones, las capillas y la industria de transformación integradas en las edificaciones. Estas edificaciones seguirían los modelos italianos $^{45}$ y se articularían en torno a patios yuxtapuestos tanto en Andalucía ${ }^{46}$ como en el Valle del Tajo.

"Un informe dirigido a su Ayuntamiento del 30 de Enero de 1634 por Gaspar Ramírez en nombre de la justicia del citado lugar de Navalmorales, nos dice que por las cargas y necesidades que han sobrevenido al Rey no están muy pobres y acabados por ser cortos y de poca vecindad (...) de manera que están a pique de despoblarse y se han ido algunos vecinos este año pasado. Para atajar y remediar esta crítica situación, consideraba el concejo de este lugar que se le debería dar licencia ‘para sembrar el término del chaparral y desmochar y entresacar algunas matas de las que hay necesidad por su espesura por haberse sembrado otros años y ser propios del concejó, ya que de él no se obtiene ahora ningún

\footnotetext{
${ }^{41}$ Palomeque, 1972: 336-337.

42 Palomeque, 1972: 346-347.

${ }^{43}$ Benito, 1965: 161.

${ }^{44}$ Palomeque, 1972: 336-337.

${ }^{45}$ Halcón, 2002.

${ }^{46}$ Olmedo, 2008.
} 


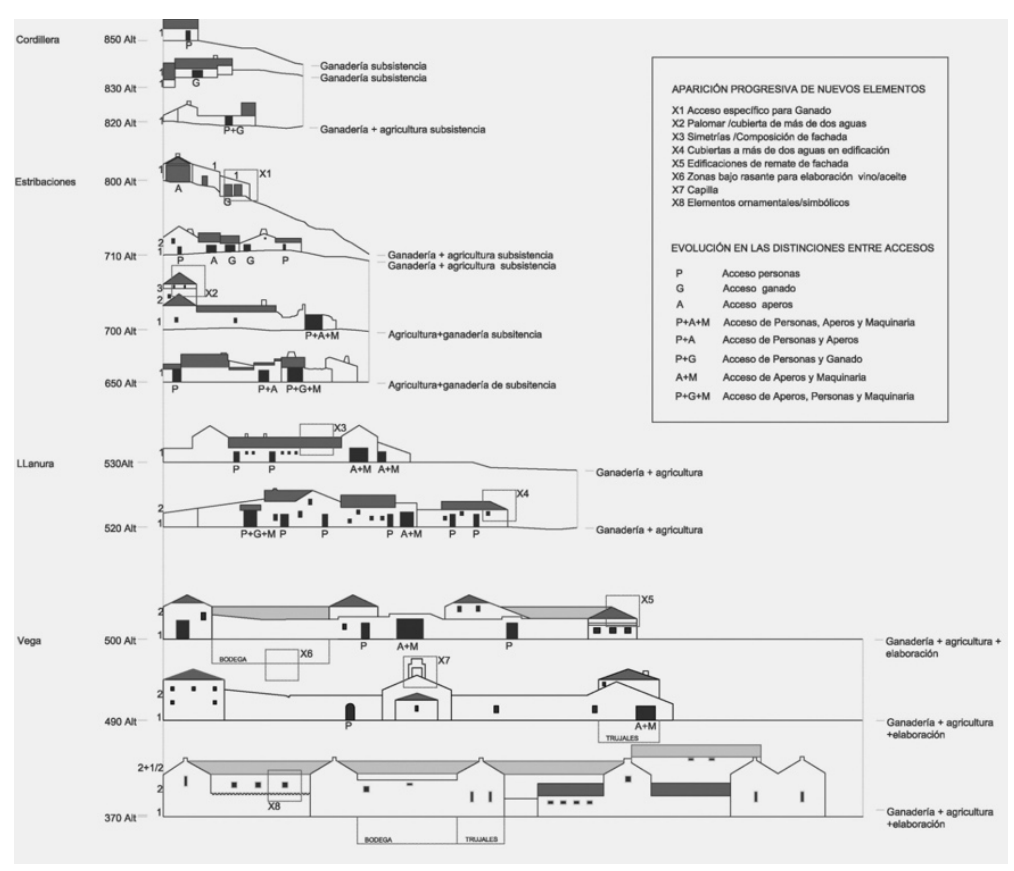

Fig. 14. Estudio comparativo en alzado de los cambios de composición, elementos y escala de las edificaciones aisladas ligadas a la agricultura en un descenso desde la cordillera de los Montes de Toledo hasta la vega del río Tajo. Fuente: la autora.

aprovechamiento, pues las dos posadas de colmenas - colmenar no cercado en monte bajoque tenía en él un vecino de Toledo las había comprado al concejo.

La llegada de los diferentes procesos de desamortización durante el s. XIX no supondrá una mejora de las condiciones de los habitantes. Por una parte el reparto del territorio seguirá siendo el mismo ya que las grandes fincas de la iglesia pasarán sin modificaciones en los lotes de venta a manos de la nueva burguesía o de la nobleza. La desamortización de la tierra de Talavera hace constar que muchas de las casas de labranza de tamaño medio estaban desde hacía siglos en manos de las órdenes eclesiásticas y fueron sólo algunas las que, con el paso de los años, acabarían realmente en manos de los campesinos. Siempre las de menor tamaño y peor categoría de tierras.

Otro de los efectos empobrecedores de las desamortizaciones fue la venta de los bienes comunales durante la desamortización de Mendizábal, esa pequeña reserva de subsistencia de los pobladores se vio afectada por los Decretos y puesta en venta de forma forzosa en casi todos los casos. En contadas ocasiones la insistencia de los Concejos conseguiría salvar parte de las Dehesas boyales.

En ningún momento se concedió a la población local la posibilidad del enriquecimiento o de la evolución en su producción con la permanencia de una estructura feudalizante hasta el s. XX. Como resultado cascos urbanos, modos de vida y edificaciones ligadas a la explotación seguirían manteniendo diferencias entre monte y vega muy similares a las que existían durante la invasión romana.

Mientras las grandes fincas incorporaban la tecnología a sus explotaciones y sus soluciones constructivas no evolucionaban excesivamente con el intercambio comercial, el tiempo permanecía más estancado cuanto mayor era la altitud. De esta forma viajamos desde una arquitectura completamente indígena en municipios como Los Alares o Gargantilla de la Jara, a estructuras económicas basadas en la ganadería más típica de época visigoda en municipios como Mensalbas. De estructuras domésticas y urbanas bereberes en municipios como Retamoso, Torrecilla de Jara o la Fresneda pensados en su ubicación para favorecer los cultivos hortícolas, pasamos a la edad Media en la llanura y a la colonización romana con las persistencias de sus tipos y explotaciones en la Vega. 
Orígenes históricos del aprovechamiento actual; la invasión romana y la expulsión de los judíos de Toledo

La inaccesibilidad, el escaso sustrato vegetal y los terrenos ricos en pizarra, relegarían a los montes durante siglos a un status de escondite, zona de huida tras invasiones, algaradas y colonizaciones. En el caso de los judíos, supondrán un refugio seguro al que muchos acudieron tras su expulsión de la ciudad de Toledo. Pero no será su presencia en el monte la que determine su nueva configuración tras el s. XV, sino justamente su ausencia de la ciudad.

Durante siglos de presencia judía en Toledo, a la que pertenecieron los montes por estar dentro de su señorío en su mayor parte, abogaría por una explotación rentable de los mismos. Esa explotación aceptaba las limitaciones de suelo, pluviometría y orografía y aprovechaba la profusión en fauna silvestre. Hasta el s. XV no se roturaron de forma masiva las tierras y se mantuvo su mera explotación como zonas de caza, carboneo, leña y pasto de ganado menor.

La mayor parte de las tierras intermedias pertenecientes al señorío de Toledo, fueron así monte hasta la expulsión de los judíos de Toledo, momento en que se comienza con mayor intensidad la roturación de montes y el inicio de su explotación agrícola. Será con la roturación iniciada hacia 1.500 cuando comience a colonizarse más intensamente la cordillera y sus vertientes norte y sur, creándose nuevos municipios y con seguridad la mayor parte de las casas de labranza que se dispersan por el territorio hasta el límite de la vega del Tajo. Esto determina que el origen la mayor parte de las casas de labranza en secano no supere probablemente los 500 años de antigüedad.

Con la expulsión y, de forma intensa, tras la desamortización, se inicia un proceso de roturación y ensayos de cultivo que se extienden hasta nuestros días sin grandes resultados y en los que el olivo, adaptable a climas extremos, con poca demanda de agua y de nutrientes ha ido ganando terreno al resto de cultivos.

En el caso de la vega pocos serán los cambios en el tipo de explotación desde época romana, ni en sus cultivos predominantes, ni en las extensiones de las fincas, ni en el tipo de propiedad. Los cultivos principales seguirán siendo el olivo, el cereal y la vid habiendo restado territorio el olivo a ésta última en los últimos siglos.

El tipo de propiedad será siempre la de las familias dominantes, en la actualidad es la aristocracia o alta burguesía la que es aún dueña de las grandes fincas a excepción de las que han pasado a manos de algún constructor enriquecido durante la últimas décadas.

Como nota de paralelismo histórico, resulta de interés la analogía existente entre las medidas tomadas por el Imperio Romano de subsidio económica las Villas rústicas -las Alimenta y Annona en expansión durante la época de Trajano- y las ayudas actuales a las explotaciones agrícolas por parte de la Unión Europea. En ambos casos las civilizaciones tienen desarrollos urbanos predominantes y desarrollos rurales limitados. Esto implica una creciente demanda de recursos alimenticios desde la ciudad y un crecimiento de las explotaciones en el ámbito rural como consecuencia. Pero las civilizaciones que desarrollan el comercio internacional, como es el caso de la actual y de la romana, comienzan también a sufrir la competencia en los precios por parte de estados con muy diferentes precios de mano de obra. Este es el principal factor de decadencia de las explotaciones agrícolas propias de la civilización dominante. La fijación de población rural no tiene como único objetivo el de abastecer a las grandes urbes, sino otro principal que es el de colonización y dominación del territorio. Se dan así situaciones paralelas con 2000 años de diferencia y soluciones análogas a las mismas problemáticas; subsidios a las explotaciones agrícolas que compensan la diferencia de precio con las del exterior y consiguen que no se abandone el territorio.

The alimenta scheme, instituted officialy in the reign of Nerva and expanded under Trajan, made Italian agriculteurs mortgages of the government by scheduling their states as surety for loans. This was a financial new deal for agriculture (...). The principal of the loans did not need to be reapid or 
amortized, and the interest was low with respect to the sum of the loan (...) the loans had more the air of subsidies to property owners (...). ${ }^{47}$

Las conclusiones acerca de las tipologías según la altitud se topan en ocasiones con excepciones que delatan alguna situación histórica o geográfica particular. Es el caso de Hontanar, adentrado ya en la cordillera, y que está rodeado de arquitectura con soluciones constructivas más bien indígenas. En su término municipal se puede encontrar un ejemplo de palomar que dista mucho por su composición del resto de construcciones de la zona. Una leve romanización del municipio puede ser el origen y se puede leer a través de los dos epígrafes funerarios votivos de tipo romano encontrados en las inmediaciones de la Torre conocida como de Malamoneda. Son inscripciones de sus oferentes, insculpidas en un bolo granítico:

\author{
Dis M]a[nibus] / Caecilius [Se]/ver[i]nus \\ a nn(norum)] / [XX]XVh(ic) s(itus) e(st) / s(it) t(ibi) t(erra) l(evis) \\ Dis Manib/us Caecilia / Parata Ca/ ecili Severi/nif(ilia) \\ an(norum) / XVh(ic) s(ita) e(st)s(it) / t(ibi) t(erra) l(evis)
}

\title{
Conclusiones
}

La arquitectura vernácula aislada en los Montes de Toledo, sus soluciones constructivas, su forma de entender y relacionarse con el territorio, se ha visto influenciada por la historia en la misma medida que por los materiales constructivos disponibles a nivel local.

La interpretación de los tipos arquitectónicos aislados que han servido a la agricultura en un que se encuentran diseminados en esa área y en un descenso hacia el río Tajo, requiere de la investigación desde tiempos prerromanos. Desde los tipos anclados en soluciones primitivas tanto en la forma de construir como en el modo en que se relacionan con el entorno, a las pequeñas vegas de arroyos y ríos que dan espacio a la agricultura y enlazan con imágenes actuales del Magreb por sus vestigios bereberes, producto de la invasión musulmana, que se ven reflejados tanto en la volumetría, como en las soluciones de cubierta y en las fábricas de muros.

Mientras las casas de labranza de la llanura y estribaciones, en pleno funcionamiento mediados del s. XX coinciden con descripciones del s. XIII, la impronta romana pervive a medida que nos acercamos al río, tanto en el uso y división del territorio como en los principios que rigen los tamaños de las explotaciones y el diseño de las edificaciones de las grandes fincas.

Adentrarse en el universo que precede a cualquier hecho construido se vuelve más complejo en este territorio, fronterizo en diferentes épocas históricas y en el que todas ellas han dejado su impronta y, con ella, una forma de entender la arquitectura doméstica, la agrícola, los recursos y la configuración del paisaje muy diferente y en estrecha relación con la altitud.

\footnotetext{
${ }^{47}$ Frazer, 1998.
} 
Bibliografía

Barroso, R./Garrobles, J. /Morín, J.: Toledo y su provincia en época visigoda. Patrimonio histórico de la provincia de Toledo. Toledo: Diputación Provincial de Toledo. (2011).

Bellal, T.: "Understanding home cultures through syntactic analysis: The case of Berber housing", Housing, Theory and Society, 21:3, (2004), pp.111-127.

Benito Ruano, E.: Toledo en el S. XV. Madrid: Consejo Superior de Investigaciones Científicas. Escuela de estudios medievales. (1965).

Caro Baroja, J.: Los pueblos de España. Madrid: Istmo. (1946).

De Olaguer-Feliú y Alonso, F.: "En torno a la rejería artística toledana". En Boletín del Seminario de Estudios de Arte y Arqueología: BSAA. Tomo 43, Valladolid, (1977), pp. 223-236

De Sousa, A. /Tôrres, F.: Civilizacioes Fluviais. Construcao da sociedade, I serie nº. 2. Lisboa: Empresa Contemporânea de ediçoes. (1946).

Frazer, A. (ed.): The Roman Villa. Villa Urbana. First Williams Symposium on Classical Architecture beld at the University of Pennsylvania, Philadelphia, April 21-22, 1990. Philadelphia: The University Museum University of Pennsylvania. (1998).

Gallego Anabitarte, A.: La desamortización de los montes de Toledo. Madrid: Marcial Pons. (1993).

Halcón Álvarez-Ossorio, F.: "Nobleza y Arquitectura: Noticias de Haciendas de Olivar del término de Carmona". En: Halcón, F./Herrera, F./Recio, Á. (eds.) (2002): Haciendas y Cortijos: Historia y Arquitectura en Andalucía y América. Sevilla: Universidad de Sevilla, (2002), pp. 115-132.

Higueruela, L.: La desamortización en Talavera de la Reina. Talavera de la Reina: Excmo. Ayuntamiento Talavera de la Reina. (1995).

Izquierdo Benito, R.: Castilla la Mancha en la Edad Media. Toledo: Servicio de Publicaciones de la Junta de Comunidades de Castilla la Mancha. (1985).

Izquierdo Benito, R.: "Una ciudad de la Marca Media: Vascos (Toledo)". En: Arqueología y Territorio Medieval, vol. 12, no 2, Jaén, (2005), pp. 35-56.

Jiménez de Gregorio, F.: “Los pueblos de Toledo". En: Diccionario de los pueblos de la provincia de Toledo hasta finalizar el siglo XVIII. Población-Sociedad-Economia-Historia, Tomos II y III. Toledo. (1966).

Leblic García, V.: El despoblado de Malamoneda. Toledo: Diputación Provincial de Toledo. (2013).

Napier, William F.P.: Campaign of Talavera. History of the war in the peninsula and in the south of France. Manchester: George Routledge and Sons. (1814).

Olmedo Granados, F.: Cortijos, Haciendas y Lagares, Arquitectura de las grandes explotaciones agrarias en Andalucía. Provincia de Córdoba, 1. Sevilla: Junta de Andalucía, (2008).

Palomeque Torres, A.: "Derechos de arancel de la justicia civil y criminal en los lugares de los propios y montes de la ciudad de Toledo anteriores a 1500". En: Anuario de Historia del Derecho Español, $\mathrm{n}^{\circ}$ 24, Madrid, (1954), pp. 87-94.

Palomeque Torres, A.: "Aportación a la Arqueología de la cuenca del Tajo; un cipo romano y un anillo hispanovisigodo". En: Revista de Archivos, Bibliotecas y Museos, Tomo LXII, n 2, Madrid, (1956), pp. 561-564.

Palomeque Torres, A.: "Nueva aportación a la Arqueología de la cuenca del Tajo; restos de una villa romana y de una iglesia visigoda". En: Revista de Archivos, Bibliotecas y Museos, Tomo LXVII, no 1. Madrid, (1959), pp. 319-345.

Palomeque Torres, A.: "El fiel del juzgado de los propios y montes de la ciudad de Toledo". En: Cuadernos de Historia de España. No 55-56, Buenos Aires, (1972), pp. 322-399. 
Porres Martín-Cleto, J.: La desamortización del s. XIX en Toledo. Toledo: Ed. Diputación de Toledo. (1966).

Prados Martínez, F.: Los Fenicios, del monte Líbano a las columnas de Hércules. Madrid: Marcial Pons. (2007).

Ravéreau, A .: Le M'Zab une lecon d'architecture'. Lucon: Ed. Sindbad actes sud. (1981).

San José, M. /Merten, R. /Perejón, A./Perejón, E. /Moreno-Eiris / Menéndez, S.: Geología y Paisaje en los Montes de Toledo centro-orientales. XIX Bienal de la Real Sociedad Española de Historia Natural Universidad de Castilla-La Mancha. Madrid: Real Sociedad Española de Historia Natural. (2011).

Urbina Martínez, D.: "La Carpetania romana y los carpetanos indígenas: tribu, etnia, nación o el país de los escarpes", Gerión, no 16, Madrid, (1998), pp. 183-208.

Villa González, R. (ed.): La Mancha occidental y la Mesa de Ocaña, II Congreso de Arqueología de la Provincia de Toledo, Vol. I Toledo: Diputación de Toledo. (2001). 